\title{
Socioeconomic Impact of COVID-19 in MENA Region and The Role of Islamic Finance
}

\author{
M. Kabir Hassan \\ University of New Orleans, United State, \\ Corresponding email: m.rabani@ku.edu.bh \\ Mustafa Raza Rabbani \\ Kingdom University, Bahrain \\ Yomna Abdullah \\ University of Bahrain Sakhir, Bahrain \\ Article History
}

Received: November 30 ${ }^{\text {th }}, 2020$ Revised: December $18^{\text {th }}, 2020 \quad$ Accepted: January $21^{\text {st }}, 2021$

\begin{abstract}
This paper analyses the socio-economic impact of the noble Corona virus (COVID-19) on 'Middle East and North Africa' (MENA) region as well as the role and opportunities of Islamic finance post COVID-19. The findings show that pandemic has affected the MENA region massively like any other region in the world. Since around $69 \%$ of the word's crude oil supply is from this region alone, this causes it to suffer from dual shocks of COVID-19 pandemic as well as the declining crude prices that is caused by shocks from both ends, negative supply shock and a negative demand shock. The 19 countries in MENA region include from some of the richest countries of the world such as, Qatar, Kuwait, and Saudi Arabia, to some of the most vulnerable, poor and war ridden countries like Yemen, Syria, and Morocco. To mitigate the adverse effects of the pandemic, we suggest some immediate actions that can be taken such as a public fund to support health system, financial support to individuals and SME's, financial support to corporations in order to prevent job loss and layoff and assurance of liquidity in domestic markets to prevent liquidity crunch. Finally, the paper analyses the role of Islamic finance in the region in recovery post COVID-19 and show that Islamic finance can be utilized as an alternative financial system in providing the relief to the COVID-19 affected people and entrepreneurs.
\end{abstract}

Keywords: Africa, COVID 19, Fintech, Economic policy

JEL Classification: C31; P19; P29; P48; Z12

Article Type: Research Paper

@ IJIEF 2021 published by Universitas Muhammadiyah Yogyakarta, Indonesia All rights reserved

DOI:

https://doi.org/10.18196/ijief.v4i1.10466
Web:

https://journal.umy.ac.id/index.php/ijief/article/view/10466

Citation:

Hassan, M. K., Rabbani, M. R., \& Abdullah, M. (2021) Socioeconomic impact of COVID-19 in MENA region and the role of Islamic finance. International Journal of Islamic Economics and Finance (IJIEF), 4(1), 51-78. DOI: https://doi.org/10.18196/ijief.v4i1.10466 
Hassan, Rabbani, \& Abdullah | Socioeconomic Impact of COVID-19 in MENA region and the Role of Islamic Finance

\section{Introduction}

\subsection{Background}

This paper analyses the socio-economic impact of COVID-19 on 'Middle East and North Africa' (MENA) region as well as it also explores the role of Islamic finance in post COVID-19 revival of economic activities. Noble Corona Virus popularly known as the COVID-19 started in the Wuhan province of China in November 2019. The first case for the COVID-19 was detected on 17 November 2019 in Wuhan city of China (Islamic Development Bank Group, 2020). Since then, it has already reached and made a mark in almost every country of the world. In first phase of the economic impact of the virus, it mainly triggered because the inter-dependence of countries on each other mainly on China, being the most important contributor in the global supply chain. In February 2020, China reacted with a massive lockdown to stop the spread of the virus and consequently it halted the economic activities. China is one the biggest exporter of raw materials and finished goods in MENA region and economic contraction in the China created spillover effect in this region also as industries in MENA are mainly dependent on China for supply of primary and intermediate raw material (Ozili, 2020). The COVID-19 is becoming critical with the daily increase in number of cases and number of deaths rising in MENA countries, mainly, Bahrain, Saudi Arabia, Egypt and Morocco.

By March 2020, COVID-19 has already reached to every country in MENA region and disrupted the economic activities. The first COVID-19 case in MENA was detected in United Arab Emirates (UAE), when a four-member family with a travel history to China was found COVID-19 positive in January 2020 (Ehrlich, Ghimire, Khraiche, \& Raza, 2020). MENA countries are characterized by the varying level of health and other economic infrastructure across the region. According to the World Bank data, there is a varying level of health infrastructure in MENA region illustrated by the number of physicians per 1000 people, for instance, Qatar has 7 physicians per 1000 population whereas in the other hand countries like Yemen have only 0.5 physician (EI Hayek et al., 2020).

MENA region is considered as one of the most important sources for the global financial stability due to its huge oil, natural gas and petroleum reserves (Boukhatem \& Ben Moussa, 2018). According to the World Atlas, it consists of the 19 countries including all 6 GCC counties, Muslim countries in Gulf and North Africa region. The term MENA is defined as the Muslim majority countries located in this region, although few countries in the region are not Muslim dominated (Policy digest, 2012). MENA region has grown in its geo- 
political importance since 'Arab Spring' of 2011, when several it is long serving dictatorial political leader was dethroned. Even before COVID-19, MENA was regarded as a troubled region due to the civil war in Iraq, Yemen and Syria resulting into the biggest civil refugee since World War II. According to an estimation from World Bank, 15 million people have fled these wars ridden countries and taken shelter in countries like, Jordan, Lebanon and Turkey.

COVID-19 is having a significant impact on the economies of the MENA region, leading to the fall in oil production, hospitality and tourism are worst affected and decline in GDP per capita income. Disruption in global supply chain has affected the domestic production, demand, and supply. COVID-19 presents an arduous threat for the vulnerable and fragile economies in MENA region as the threat is more alarming for the countries with low resources and in a situation of continuous war and conflict, such as Afghanistan, Iraq, Syria, Yemen, Lebanon, and Somalia. Remittances constitutes of around 14\% of GDP in fragile economies of the MENA region and it is expected to go down by $20 \%$ due to fall in global income (Li, Chung, Pireku, Beitzel,, Sanborn, Tang, Hammer, Ritter, Wan, Berry, \& Hang, 2020). It is also going to hit the GDP of these fragile economies as it is expected to shrink by average 7\% across 2020 as compared to the average growth of about $2.5 \%$ in 2019 , consequently it will lead to fall in GDP per capita from \$2900 in 2018-19 to \$ 2100 in 2020 (IMF, 2020). The oil exporting economies will be the biggest hit due to fall in crude oil prices, creating a fiscal ripple effect by reducing the private consumption expenditure and reduction in energy investments.

Islamic finance and banking are a significant part of the development agenda of the countries in the MENA region. It has emerged as the growth stimulator in the region as there is clear evidence that Islamic finance stimulated the growth in this region (Nicola et al., 2020). Since, Islamic finance is accepted as the ethical finance and based on the rules and principles prescribed by the sharia, it is expected to play a huge role in recovery of the economies postCOVID-19. Islamic finance in combination with the financial technology will be the most important tool in fight against the economic consequences of the COVID 19 (Hassan, 2020). Islamic finance has several financial services like, Qardh-Al-Hasan, Zakat, Waqf and Social Sukuk which are tailor made for the crises and pandemic-like situation (Hassan, Rabbani \&Yomna, 2020; Syed, Khan, Rabbani \& Thallasinos, 2020)

\subsection{Objectives}

This paper investigates the socio-economic impact of COVID 19 and role of Islamic finance as a post COVID-19 response in the region. The emerging and 
Hassan, Rabbani, \& Abdullah | Socioeconomic Impact of COVID-19 in MENA region and the Role of Islamic Finance

budding response of literature rated to COVID-19 has given little response to all important MENA countries. The findings show that COVID-19 has created a massive disruption in supply chain, falling production, falling domestic demand due to loss of income and loss of jobs. The governments and policymakers should take immediate account of the prevailing situation and devise an enduring to take the economies out of it. We suggest that Islamic finance can be entrusted with the more decisive and important role in post COVID-19 revival.

Our paper contributes to the existing strand of literature in the several ways. First, we are the first to document the socio-economic impact of COVID 19 in MENA region. Second, role of Islamic finance in recovery from COVID-19 has not be examined and analyzed so far, it will prove to be an asset for the governments and policymakers. The findings of the study will also add to the growing list of literature conducted on other countries and regions of the world such as (Hassan et al. 2020; Mohammad et al. 2020; Wójcik 2020). Finally, the paper will contribute the filament of literature on the impact of COVID-19 on various sectors of the economy (Hassan et al., 2020; Khan et al., 2021; Rabbani, Abdullah, Bashar, Khan and Ali, 2020; Abdullah, Hassan and Rabbani 2020; Duszak, Maze, Sessa, Fleshon, Golding, Nikola, Hughes 2020; Ghani, 2020; Hepburn, O'Callaghan, Stern, Stiglitz and Zenghelis, 2020) Our study will open avenue for future work to conduct a methodologically rigorous research on the socio-economic impact of COVID 19 and role of Islamic finance aftermath.

The present study is divided into the five parts. The first part introduces the paper and highlights the objectives of the study whereas, second part reviews the available literature on COVID-19 and provides the background theory. Third part of the study presents the Methodology used for the study. In fourth part we analyses the data related to COVID-19 and its economic impact on various sections of the society. Fourth part also discusses the solution to the economic damage created by the pandemic and proposes Islamic social finance tool as the probable solution. In fifth and final section, we conclude and provide the recommendations based on the analysis and discussion.

\section{Literature Review}

\subsection{Background Theory}

Economic impact of COVID-19 is highly uncertain, and it is difficult to devise a proper tool to measure its exact effect on the economy which makes it even difficult for the policymakers and governments to formulate an appropriate strategy and macroeconomic response to tackle the economic consequences 
of the virus (McKibben \& Fernando, 2020). (Achou et al., 2020) presents a theory of Keynesian supply shocks, where they argue that the supply shocks always stimulate the aggregate demand than the shocks themselves. They further conclude that the economic consequences associated with the COVID19 such as, lay off, shutting down of the industries, unemployment and firm exits may have this feature. (Erceg, Ružojčić, and Galić 2020; Catherine, Miller, and Sarin 2020) presented a comprehensive review of the socio-economic review of COVID-19 pandemic where they divided the total economy in to three sectors, primary, secondary and tertiary. Primary sector included the industries involved in extraction of raw material such as agriculture, petroleum, and oil etc. They concluded that there is around 20\% drop in the prices of agricultural produce and in the oil and energy sector the deceleration in the number of COVID cases and caused some stabilization in oil prices and there is still much uncertainly. The secondary sector includes manufacturing industry. They concluded that on an average manufacturing industry are predicted to reduce its global production by a significant margin. They included education, healthcare and finance industry in the tertiary sector and concluded that, this is the worst hit sector among the three and immediate liquidity is required in this sector.

\subsection{Previous Studies}

In the past few of months there has been a wave of research on economic impact of COVID-19 and ways to overcome the consequences brought in by the COVID-19 and its associated measures. (Sharif et al., 2020) argues that most of the studies focuses on the large problems that humanity has faced in a long time and it lacks substance as far as investigation into economic impact of COVID-19 is concerned. Most of the studies are of general nature focusing on a country or region.

Hassan, et al (2020) have done an inclusive analysis of post COVID-19 economic impact and role of Islamic finance. They concluded that the COVID19 has shocked the entire world with its swift spread across the globe causing a pause to the normal way of living. Economies are on the verge of crashing, banks are facing liquidity problems, regulators do have the liberty of taking time to come up with solutions and what not. Islamic banks were already facing issues due to fall in crude prices in Saudi Arabia and Iran. With COVID19 , the problems are only getting worse, in countries where EMIs are delayed for a period of 3-6 months, banks must survive with literally 0 cash inflows. However, FinTech seems to be booming faster than ever in this period due to the need of living a contactless lifestyle. Islamic Finance seems to have a solution for building up the falling businesses and economies because of the 
foundation on what sharia-based financing is assembled. As per a French economist, M. Allais, the only way to recover from the damages caused by the coronavirus pandemic is through structural reform. The structural reform must be in way of reduced burden on consumers and increase support for them to get back up. The projected reform requires the interest rate to be charged at $0 \%$ and tax rate to be around $2 \%$. Islamic Finance provides tools to support affected communities such as Zakat, Qard Al Hasan, Social Sukuk and Waqf. These social tools can be used to recover from the blow caused by the COVID-19 impact to needy individuals, small and medium sized enterprises (SMEs).

The coronavirus pandemic has hit a pause button to normal life and adversely affected small businesses and mainly the poor community. This study provides a solution to help small businesses recover and sustain this highly unstable and depressed economy. The implementation of Islamic finance tools such as, Qard Al Hasan and Zakat jointly along with FinTech as a solution is explored in this research. Qard Al Hasan are loans provided without any expectation of being repaid while Zakat is the Islamic tax which must be paid by every eligible Muslim. A model is developed by (Mohammad et al., 2020) to provide flexible loans using artificial intelligence and natural language processing (NLP). This model comprises of three modules - 1) Gathering data to assist in decision making process, 2) To recommend a potential list of interested lenders 3) To uphold records of information and deliver required communication. A webbased platform of this model can be achieved with the use of data analytics, NLP and artificial intelligence resulting in transparency and efficiency. FinTech will provide Islamic Finance with the necessary tools to help the community by alleviating poverty and ensuring social justice, which is the foundation of shariah based finance. With the use of NLP and artificial intelligence, this model of Zakat and Qard Al Hasan can benefit many businesses and boost the economy as a result. However, huge costs would have to be incurred to develop such a platform and with governments already over-burdened, it's a hard path ahead (Mohammad et al. 2020; Damak, Roy, and Mensah 2020;) conduct an empirical analysis on Islamic equity investments indices around the world and concluded that Islamic finance indices have outperformed their conventional counterpart in the first quarter of 2020. With the COVID outbreak, investors find Islamic equity investments as safe heaven asset due to its stringent screening it also hedging benefits to the investors. They further concluded that the excess benefits provided by the Islamic indices are due to the systemic risk, it means that the hedging benefit comes at an additional cost. 
Hassan, Rabbani, \& Abdullah | Socioeconomic Impact of COVID-19 in MENA region and the Role of Islamic Finance

\section{Methodology}

Following the World Bank, we divide the 19 MENA countries based on the availability of oil resources and the size of their native populations. The MENA region consists of 19 countries which can be divided in to three groups namely Gulf Cooperation Council (GCC), developing oil exporters and developing oil importers (MENA world bank monitor, 2018). We collect data regarding the cases and deaths of COVID-19 during the period March 2020 to July 2020 from the World Health Organization (WHO). We employ discourse analysis which is used for analyzing a social issue through a variety of discourse (Wodak \& Meyer, 2011).

The period of analysis is from 1st January 2020 to 1st July 2020. Table 1 presents the various data sources used. In the GCC countries, the first COVID case was detected on 25th January 2020 in the United Arab Emirates (UAE) as four members of a family with a travel history to Wuhan city in China was confirmed with a positive COVID case. Our sample period allows us to capture all MENA countries governments' response measures and the impact of those policy on individuals and institutions. Furthermore, this period involves a strict lockdown and announcement of governments' stimulus packages.

Table 1. Data Sources

\begin{tabular}{|c|c|c|}
\hline Data & Source & Period of Data \\
\hline COVID 19 cases & WHO and Worldometer & $\begin{array}{l}25^{\text {th }} \text { January } 2020 \text { to } 22^{\text {nd }} \\
\text { Nov. } 2020 .\end{array}$ \\
\hline $\begin{array}{l}\text { Mobility across GCC } \\
\text { countries }\end{array}$ & Gulf Business Magazine & $\begin{array}{l}25^{\text {th }} \text { January } 2020 \text { to } 22^{\text {nd }} \\
\text { Nov. } 2020 .\end{array}$ \\
\hline Curfew across countries & $\begin{array}{l}\text { Respective government } \\
\text { websites }\end{array}$ & $\begin{array}{l}25^{\text {th }} \text { January } 2020 \text { to } 22^{\text {nd }} \\
\text { Nov. } 2020 .\end{array}$ \\
\hline Policy response & $\begin{array}{l}\text { IMF and respective } \\
\text { government websites. }\end{array}$ & Updated till 1 July 2020. \\
\hline Foreign aid spending & Media sources & Updated till 1 July, 2020. \\
\hline
\end{tabular}


Hassan, Rabbani, \& Abdullah | Socioeconomic Impact of COVID-19 in MENA region and the Role of Islamic Finance

\section{Result and Analysis}

\subsection{Trend Analysis}

The number of total confirmed cases in the MENA countries represents about $6 \%$ of the global numbers. Whereas, the number of total deaths cases in the MENA countries represents about $7 \%$ of the global numbers. The GCC countries has the highest number of confirmed cases compared to the other two regions of the MENA countries. Table 2 presents the data on total (new) confirmed cases in last 7 days and Change in new cases in last 7 days as of 22 Nov. 2020. While, the highest total number of deaths is seen in developing oil exporters and the lowest number of deaths is observed in GCC countries. A possible reason this trend is the good health system in GCC countries which prevents the deterioration of the health status of the active cases.

Table 2. Total New and Confirmed Cases in Last 7 days as on 22 November 2020

\begin{tabular}{|c|c|c|c|c|c|c|}
\hline Region & $\begin{array}{c}\text { New } \\
\text { cases in } \\
\text { last } 7 \\
\text { days (\%) }\end{array}$ & $\begin{array}{l}\text { Change in } \\
\text { new } \\
\text { cases in } \\
\text { last } 7 \\
\text { days * }\end{array}$ & $\begin{array}{l}\text { Cumulative } \\
\text { cases (\%) }\end{array}$ & $\begin{array}{c}\text { New } \\
\text { deaths } \\
\text { in last } 7 \\
\text { days (\%) }\end{array}$ & $\begin{array}{l}\text { Change in } \\
\text { new } \\
\text { deaths in } \\
\text { last } 7 \\
\text { days* }\end{array}$ & $\begin{array}{l}\text { Cumulative } \\
\text { deaths (\%) }\end{array}$ \\
\hline Europe & $\begin{array}{l}1771 \\
673 \\
(44 \%)\end{array}$ & $-6 \%$ & $\begin{array}{l}16873383 \\
(29 \%)\end{array}$ & $\begin{array}{l}32684 \\
(49 \%)\end{array}$ & $10 \%$ & $\begin{array}{l}375368 \\
(27 \%)\end{array}$ \\
\hline Americas & $\begin{array}{l}1603 \\
498 \\
(39 \%)\end{array}$ & $11 \%$ & $\begin{array}{l}24563600 \\
(42 \%)\end{array}$ & $\begin{array}{l}22005 \\
(33 \%)\end{array}$ & $15 \%$ & $\begin{array}{l}697740 \\
(51 \%)\end{array}$ \\
\hline South-East Asia & $\begin{array}{l}351822 \\
(9 \%)\end{array}$ & $-6 \%$ & $\begin{array}{l}10367553 \\
(18 \%)\end{array}$ & $\begin{array}{l}4706 \\
(7 \%)\end{array}$ & $4 \%$ & $\begin{array}{l}158566 \\
(12 \%)\end{array}$ \\
\hline $\begin{array}{l}\text { Eastern } \\
\text { Mediterranean }\end{array}$ & $\begin{array}{l}250746 \\
(6 \%)\end{array}$ & $5 \%$ & $\begin{array}{l}3796649 \\
(7 \%)\end{array}$ & $\begin{array}{l}6299 \\
(9 \%)\end{array}$ & $10 \%$ & 96354 (7\%) \\
\hline Africa & $\begin{array}{l}47106 \\
(1 \%)\end{array}$ & $15 \%$ & $\begin{array}{l}1446041 \\
(2 \%)\end{array}$ & $\begin{array}{l}1088 \\
(2 \%)\end{array}$ & $30 \%$ & $32538(2 \%)$ \\
\hline Western Pacific & $\begin{array}{l}36046 \\
(1 \%)\end{array}$ & $9 \%$ & $\begin{array}{l}834216 \\
(1 \%)\end{array}$ & 439 (1\%) & $1 \%$ & $16816(1 \%)$ \\
\hline Global & $\begin{array}{l}4060 \\
891 \\
(100 \%)\end{array}$ & $1 \%$ & $\begin{array}{l}57882183 \\
(100 \%)\end{array}$ & $\begin{array}{l}67221 \\
(100 \%)\end{array}$ & $11 \%$ & $\begin{array}{l}1377395 \\
(100 \%)\end{array}$ \\
\hline
\end{tabular}

Source: WHO epidemiological update - 24 November 2020 
Hassan, Rabbani, \& Abdullah Socioeconomic Impact of COVID-19 in MENA region and the Role of Islamic Finance

Table 3. A six months' trend analysis

\begin{tabular}{lcccccc}
\hline & 12 August & 12-July & 12-June & 12-May & 12-April & 12-March \\
$\begin{array}{l}\text { Total confirmed } \\
\text { cases }\end{array}$ & 20162474 & 993,426 & 568,430 & 240,237 & 92,137 & 9,914 \\
New cases & 214985 & 12,926 & 12,565 & 7,392 & 3,488 & 1,336 \\
$\begin{array}{l}\text { Total confirmed } \\
\text { deaths }\end{array}$ & 737417 & 24,762 & 13,281 & 8,686 & 5,111 & 367 \\
New deaths & 4835 & 409 & 236 & 79 & 173 & 67 \\
\hline
\end{tabular}

Table 3 presents a six months' trend analysis for the total (new) number of confirmed and the total (new) number of deaths (WHO stopped issuing daily situation report 6 August onwards). There has been an evidenced growth in both the number of cases and deaths during our sample period. The highest growth rate in the total number of confirmed cases is seen in April of about $829.4 \%$ while the lowest growth rate is evidenced in July of about $74.7 \%$. A similar trend is observed in the total numbers of deaths as the highest growth rate is documented in April. While the lowest growth rate in the total number of deaths is seen in June of about $52.9 \%$. Regarding the new cases, the lowest growth rate in new cases is evidenced in July, while, there was a drop in the number of new deaths in May as shown by the negative growth rate compared to the number of deaths in April.

Figure 1 documents the trend analysis for five months in the GCC countries. We observe a continuous increase in the total number of confirmed cases. Whereas, the number of deaths remains relatively low in the GCC countries. A huge increase in the total number of confirmed cases is seen in April, being the highest growth rate of about $1964 \%$ compared to the total number of confirmed in March. While, the growth rate in the numbers of total confirmed cases and deaths is at lowest level in July, suggesting that the virus is spreading at a lower rate compared to earlier months. 
Hassan, Rabbani, \& Abdullah | Socioeconomic Impact of COVID-19 in MENA region and the Role of Islamic Finance

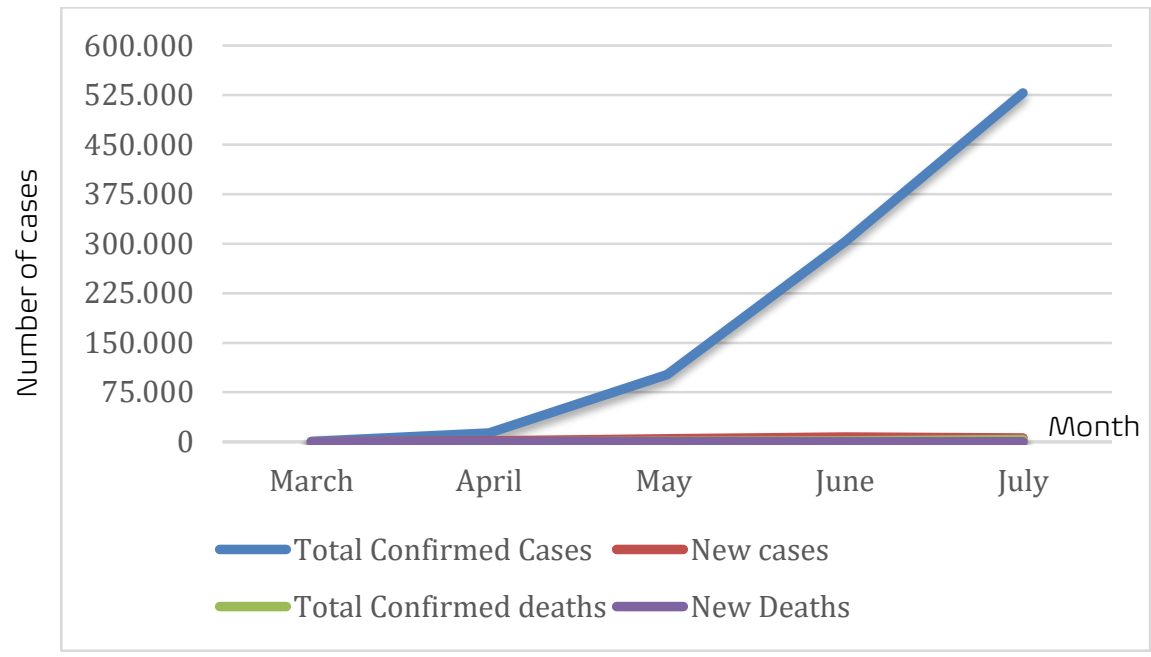

Figure 1. Trend analysis in GCC countries

Figure 2 presents the numbers of cases and deaths in developing oil exporter countries. The highest growth rate in the total number of confirmed cases is seen in April of about 705\%, whereas the lowest growth rate is evident in May of about $61 \%$. Regarding the total number of deaths, the highest growth rate is also seen in April and the lowest growth rate of $36 \%$ is observed in June.

Figure 3 presents the number of confirmed cases in oil importer countries. A similar trend to the other two groups of MENA, he highest growth rate in the total number of confirmed cases is seen in April of about 3114\%, whereas the lowest growth rate is evident in July of about $99 \%$. Regarding the total number of deaths, the highest growth rate is also seen in April and the lowest growth rate of $115 \%$ is observed in June.

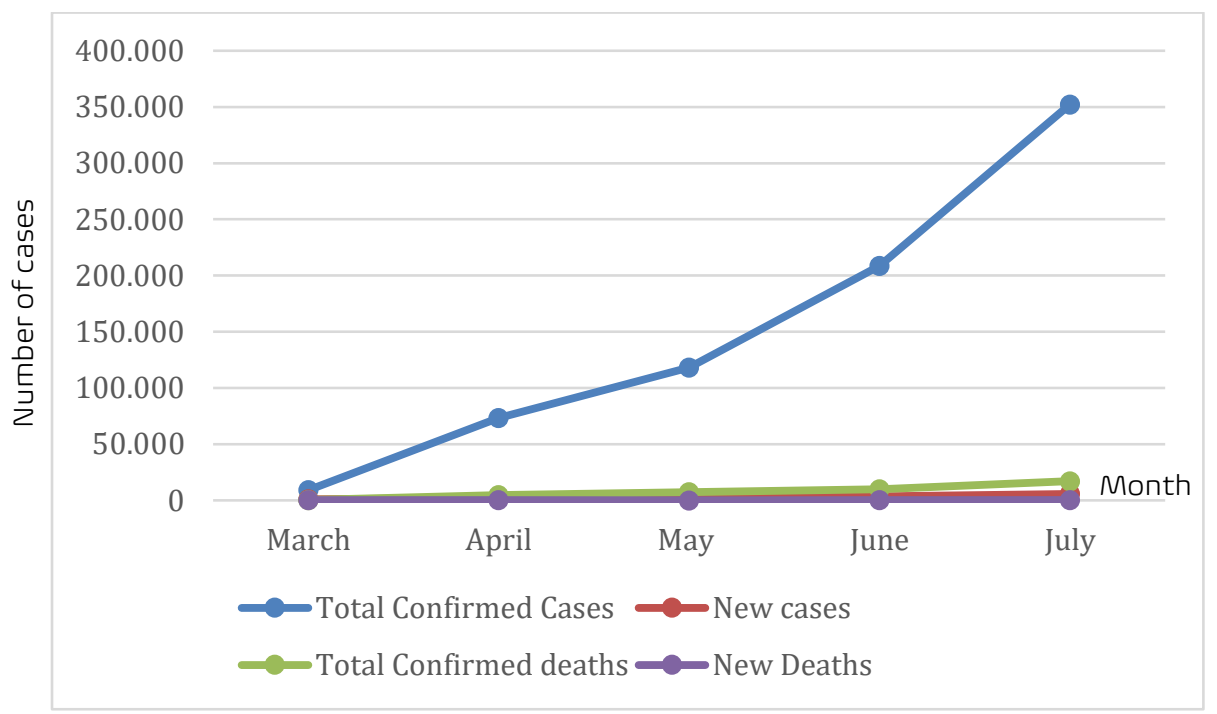

Figure 2. Trend analysis in developing oil exporter countries 
Hassan, Rabbani, \& Abdullah | Socioeconomic Impact of COVID-19 in MENA region and the Role of Islamic Finance

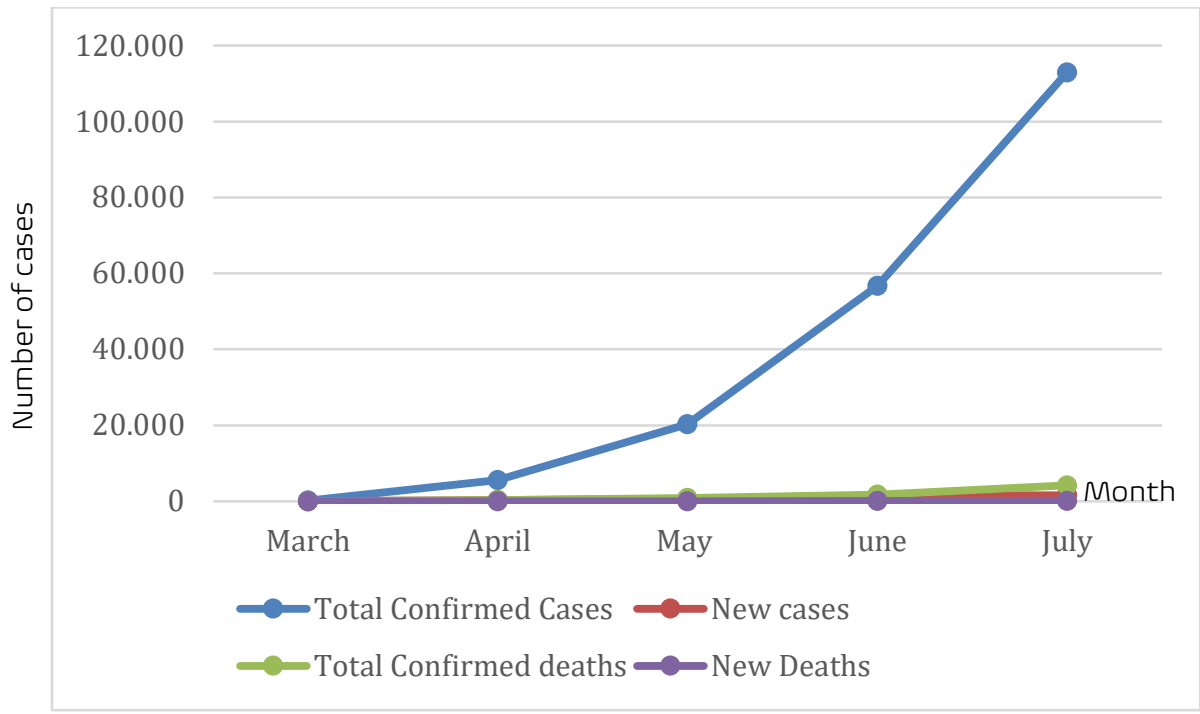

Figure 3. Trend analysis in developing oil importer countries

Table 4 reports the average growth rate during the five months, from March to July 2020, in the total number of confirmed cases and deaths across the three groups of MENA countries. Overall, the highest average growth rate in total confirmed cases as well as the total number of deaths is found in oil importer countries. Some possible reasons for this trend are inadequate precautionary measures and poor health systems.

Table 5 show the country-level situation of COVID-19 in MENA countries. The highest number of confirmed cases and death is found in Iran with 841,308 cases. Whereas, the lowest number of confirmed cases is seen in Yemen and the lowest number of deaths is in Somalia. There are no countries with zero reported new cases or death in last one week as on 22 Nov. 2020. The total reported cases are on the declining side in some countries but second wave has already been started in the countries like Iran and Jordan. two countries with zero reported new cases on 12th July 2020 which are Syria and Djibouti, while, 8 of the 19 MENA countries have recorded zero death on that day. Within the GCC countries, Iran has the highest number of confirmed cases. In the developing oil exporters' countries, Iran also holds the first place in the number of total confirmed (deaths) cases. Egypt has the highest number of total confirmed (deaths) cases among the developing oil importers. 
Hassan, Rabbani, \& Abdullah | Socioeconomic Impact of COVID-19 in MENA region and the Role of Islamic Finance

Table 4. Average Growth Rate during the Five Months in the Total Number of Confirmed Cases and Deaths

\begin{tabular}{lll}
\hline & $\begin{array}{l}\text { Average growth rate } \\
\text { in total confirmed } \\
\text { cases }\end{array}$ & $\begin{array}{l}\text { Average } \\
\text { growth rate in } \\
\text { total deaths }\end{array}$ \\
\hline GCC & $725 \%$ & $279 \%$ \\
Developing Oil Exporters & $228 \%$ & $341 \%$ \\
Developing Oil Importers & $913 \%$ & $1658 \%$ \\
\hline
\end{tabular}

Table 5. COVID-19 Situation in MENA countries as of 22 November 2020

\begin{tabular}{|c|c|c|c|c|c|c|}
\hline $\begin{array}{c}\text { Reporting } \\
\text { Country/Te } \\
\text { rritory/Are } \\
\text { a }\end{array}$ & $\begin{array}{c}\text { New cases } \\
\text { in last } 7 \\
\text { days }\end{array}$ & $\begin{array}{c}\text { Cumulative } \\
\text { cases }\end{array}$ & $\begin{array}{c}\text { Cumulative } \\
\text { cases per } 1 \\
\text { million } \\
\text { population }\end{array}$ & $\begin{array}{c}\text { New } \\
\text { deaths in } \\
\text { last } 7 \text { days }\end{array}$ & $\begin{array}{c}\text { Cumulative } \\
\text { deaths }\end{array}$ & $\begin{array}{c}\text { Cumulative } \\
\text { deaths per } \\
1 \text { million } \\
\text { population }\end{array}$ \\
\hline Iran & 91783 & 841308 & 10016 & 3293 & 44327 & 528 \\
\hline Jordan & 36856 & 178161 & 17461 & 468 & 2172 & 213 \\
\hline Morocco & 32751 & 320962 & 8696 & 559 & 5256 & 142 \\
\hline Iraq & 16640 & 533555 & 13265 & 302 & 11925 & 296 \\
\hline $\begin{array}{l}\text { Lebanon } \\
\text { United }\end{array}$ & 10975 & 115242 & 16884 & 88 & 894 & 131 \\
\hline $\begin{array}{c}\text { Arab } \\
\text { Emirates }\end{array}$ & 8650 & 157785 & 15953 & 20 & 548 & 55 \\
\hline Tunisia & 8132 & 87471 & 7401 & 473 & 2752 & 233 \\
\hline Libya & 4180 & 76808 & 11178 & 73 & 1068 & 155 \\
\hline Kuwait & 3393 & 139734 & 32720 & 28 & 863 & 202 \\
\hline Egypt & 2129 & 112676 & 1101 & 93 & 6535 & 64 \\
\hline $\begin{array}{l}\text { Saudi } \\
\text { Arabia }\end{array}$ & 2084 & 355034 & 10198 & 120 & 5761 & 165 \\
\hline Oman & 1918 & 121360 & 23765 & 39 & 1365 & 267 \\
\hline Qatar & 1492 & 137062 & 47574 & 1 & 235 & 82 \\
\hline Sudan & 1111 & 15839 & 361 & 74 & 1193 & 27 \\
\hline Bahrain & 1068 & 85591 & 50301 & 5 & 338 & 199 \\
\hline Syria & 541 & 7154 & 409 & 31 & 372 & 21 \\
\hline Somalia & 81 & 4382 & 276 & 1 & 108 & 7 \\
\hline Yemen & 1 & 2073 & 70 & 2 & 605 & 20 \\
\hline
\end{tabular}

\subsection{Socio-economic Impact of COVID-19 on MENA Countries}

\subsubsection{Impact on Health Care Sector}

COVID-19 is a health crisis, therefore, it is expected to have a significant impact on the health care sector. The impact of the pandemic depends on the status of the health care infrastructure which differ across the MENA countries. Overall, the health care sector measured by the number of physician per 1,000 people is poor in MENA region compared to Europe and North America. Table 6 reports these statistics during the period 1990-2017. 
Hassan, Rabbani, \& Abdullah | Socioeconomic Impact of COVID-19 in MENA region and the Role of Islamic Finance

Table 6. Number of physicians per 1,000 people

\begin{tabular}{lllll}
\hline Region & 1990 & 2000 & 2010 & 2017 \\
\hline MENA & 0.69 & 1.25 & 1.57 & 1.32 \\
European Union & 2.95 & 3.08 & 3.35 & 3.74 \\
North America & 1.83 & 2.52 & 2.39 & 2.61 \\
\hline
\end{tabular}

Source: https://data.worldbank.org/

Compared to other countries in MENA region, the GCC countries have a good health care sector as in all of the 6 GCC countries, the number of doctors and nurses are above the world average (GCC STAT, 2020). Compared to other GCC countries, Kuwait is considered to be best in terms of number of hospital beds, doctors and nurses (GCC STAT, 2020). The negative impact of COVID-19 on GCC health care sector include the burden on the current health care systems, delay on pre-COVID-19 scheduled appointments and the effect on some health departments such as physical therapy and dental services as some of these services were banned for some time as a measure of social distancing (GCC STAT, 2020).

In a different context, Egypt has a low level of health care infrastructure, supplies and protective tools, which caused the pandemic to affect a large number of medical staff (Ozili, 2020). A similar concern was raised in Morocco due to the fear of the burdening of the current health care system. Overall, the World Bank had concern on the impact of COVID-19 on African countries due to their poor health care systems. Some of the MENA countries such as Yemen, Libya and Syria are suffering from political conflicts which makes their health responses more challenging. Fekri and Al-Awlaqi (2020) indicate that the health care system in Yemen is fragile and there are concerns whether it will be able to cope with the spread of COVID-19. The concerns include the lack of protective equipment, shortage of medicines and supplies, limited number of laboratories and isolation locations. Mikael and Al-Jumaili (2020) argue that the health care sector in Iraq faces several challenges in reducing the spread of the virus. These challenges include shortage of protective equipment, hygiene tools, quarantine facilities and ambulances and low level of public awareness.

In attempts to support the health systems and slow the spread of the virus, the World Bank has supported countries with medical supplies, technical assistance and policy advice (World Bank, 2020). The World Bank recommends that the government spending need to be devoted to health care sector along with establishment of a strategy to reduce the spread of the virus. It also suggested that there will be a need to continue in random tests and boost the capacity of the department of Intensive care unit. 
Hassan, Rabbani, \& Abdullah | Socioeconomic Impact of COVID-19 in MENA region and the Role of Islamic Finance

\subsubsection{Impact on Stock Markets}

The global stock markets have reacted negatively to the spread of COVID-19 due to the increase in risks, low demand and supply disruptions. The stock markets in the MENA region have documented a similar trend. According to the GCC Statistical center, the stock markets in the GCC countries have recorded a negative return starting from January 2020 to March 2020. Figure 4 presents the return of selected MENA stock markets during the period January 2020 to April 2020.

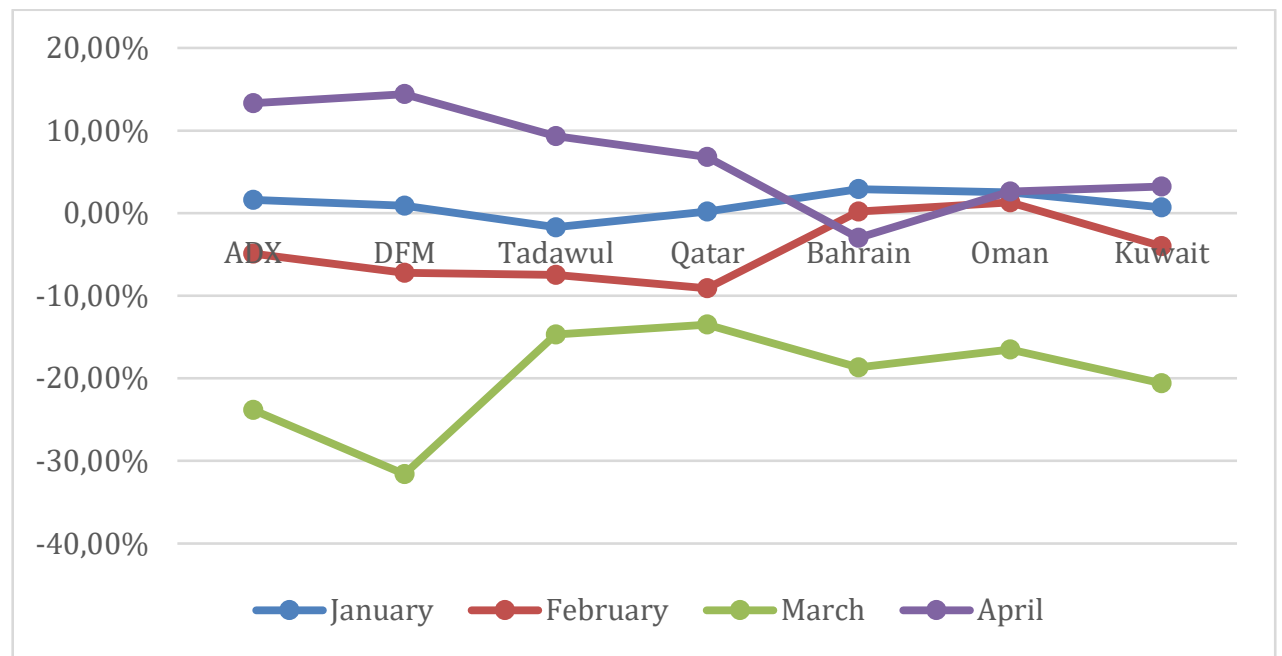

Figure 4. Performance of selected MENA stock markets during the period January 2020 to April 2020.

The highest drop was seen in March of about 15.7\%, however, in the next month the stock markets recovered achieving a return of $9 \%$. The highest drop in February was in Qatar market by about 9.1\%, whereas in March, Dubai financial market, had the highest decline of $31.6 \%$ which also had the highest increase in return in April 2020 of about 14.4\%. Oman was the best performing market during the period from January to April 2020, with the lowest decline of $2.5 \%$. (Ozili \& Arun, 2020) show that companies listed in Casablanca Stock Exchange have evidenced a drop in value in March 2020 due to the announcement of confirmed cases of COVID-19. The Egyptian stock market index (EGX 30) has dropped by 39\% during the period from February to April 2020 (OECD, 2020).

\subsubsection{Impact on Tourism Sector}

According to the World Travel and Tourism Council, the tourism sector is about $\$ 245$ billion of the GDP of the Middle East Countries and it provides 6.7 million jobs. Table 7 reports the statistics of Tourism and Travel GDP in 2018 and three possible scenarios in 2020. The Council argues that the baseline scenario suggests that the COVID-19 will cause a 51\% job loss and in its 
Hassan, Rabbani, \& Abdullah | Socioeconomic Impact of COVID-19 in MENA region and the Role of Islamic Finance

Table 7. Impact of COVID-19 on Tourism and Travel GDP

\begin{tabular}{ccccc}
\hline Region & 2019 & Best case loss & $\begin{array}{c}\text { Baseline case } \\
\text { loss }\end{array}$ & Worst case loss \\
Middle East & \$245 Billion & \$9 Billion & \$125 Billion & \$179 Billion \\
Africa & \$168 Billion & \$53 Billion & \$75 Billion & \$120 Billion \\
\hline
\end{tabular}

Source: World Travel and Tourism Council

contribution to the GDP. The number of international (domestic) visitors will decline by $54 \%$ (35\%). While in the African countries, the travel and tourism adds $\$ 168$ million to the GDP and provides 24.6 million jobs. There will be about $44 \%$ drop in number of jobs and $45 \%$ decline in its contribution to the GDP due to the pandemic. The number of international (domestic) visitors will decline by $50 \%$ (35\%).

\subsection{Economic Evidence}

According to the World Bank, the GDP growth in MENA countries is expected to decline by $1.1 \%$ during 2020 due to the health concerns, social distancing measures and the crash in the oil prices. Furthermore, the real GDP per capita is anticipated to contract by $2.6 \%$ during this year because of the decline in demand mainly in oil and tourism sectors. Based on the GCC Statistical center, the GDP of GCC countries is anticipated on average to contract by $2.2 \%$ in 2020, while it will recover it 2021 to reach on average to $0.4 \%$. The oil sector is one of the main sectors for MENA countries as many of them are oilexporters countries. The output of the oil exporter countries is predicted to contract by $3.9 \%$ and $0.6 \%$ is the expected growth rate in oil-importers countries. Overall, it is anticipated that the pandemic will cost the MENA countries about US\$116 billion which represents 3.7\% their GDP in the year 2019 (World Bank, 2020).

Table 8 shows the projected real GDP growth of MENA countries during 2020 based on the International Monetary Fund (IMF) estimations. The majority of MENA countries are expected to have a negative rate of real GDP growth due to the pandemic and decrease in oil prices. The only two countries with positive GDP growth are Egypt and Djibouti. The highest decline in GDP growth is expected in Libya, followed by Lebanon. While, the lowest contraction in the GDP is anticipated to be in Kuwait.

The pandemic has started as a health crisis but then became an economic recession due to low demand caused by social distancing, shut down policies, and fear. This low demand in turn had affected the supply side which resulted in the closures of some companies, laid of employees and low revenues. 
Hassan, Rabbani, \& Abdullah | Socioeconomic Impact of COVID-19 in MENA region and the Role of Islamic Finance

Table 8. Projected Real GDP growth in MENA countries during 2020

\begin{tabular}{|c|c|}
\hline Country & $\begin{array}{c}\text { Projected Real } \\
\text { GDP growth in } \\
2020(\%)\end{array}$ \\
\hline \multicolumn{2}{|l|}{ GCC } \\
\hline Bahrain & -3.6 \\
\hline Kuwait & -1.1 \\
\hline Oman & -2.8 \\
\hline Qatar & -4.3 \\
\hline Saudi Arabia & -6.8 \\
\hline UAE & -3.5 \\
\hline \multicolumn{2}{|c|}{ Developing Oil Exporters } \\
\hline Algeria & -5.2 \\
\hline Iran & -6 \\
\hline Iraq & -4.7 \\
\hline Libya & -58.7 \\
\hline Yemen & -3 \\
\hline Syria & NA \\
\hline \multicolumn{2}{|c|}{ Developing Oil Importers } \\
\hline Djibouti & 1 \\
\hline Egypt & 2 \\
\hline Jordan & -3.7 \\
\hline Lebanon & -12 \\
\hline Morocco & -3.7 \\
\hline Tunisia & -4.3 \\
\hline West Bank \&Gaza & NA \\
\hline
\end{tabular}

\subsection{Sociological Evidence}

The pandemic has magnified some of the challenges faced by MENA countries such as the inefficiency in the public sector, the low competitiveness between businesses, and high unemployment rate of about $25 \%$ pre-pandemic, across youth and females which is a main problem given that majority of the population are under 35 years and $40 \%$ of the unemployed are women (World Bank, 2020). Similarly, the unemployment rate is also expected to increase in the GCC countries due to the high number of employees in the services sector which was adversely affected by the pandemic (Gulf Health Council, 2020). Furthermore, the poverty is a main concern in some of the MENA countries, as in 2011, 42\% of MENA's population lived on daily income below US\$5.50 (World Bank, 2020). The poverty problem makes the implementation of precautionary measures, such as proper hand washing and hygiene, social distancing and work from home scheme, very challenging.

As a precautionary measure, most countries worldwide have taken the decision of school's closure. The North African countries have closed their 
Hassan, Rabbani, \& Abdullah | Socioeconomic Impact of COVID-19 in MENA region and the Role of Islamic Finance

schools by middle of March, whereas the GCC countries have taken early closure decision by the end of February. UNESCO suggest the continuation of education using virtual learning platforms. The success of this suggestion depends on the availability of such platforms and tools in a country, which is not the case in all MENA countries. Furthermore, staying at home may increase violence, decrease social networking and activities between students.

\subsection{Role of Islamic Finance and Opportunities}

Islamic finance is considered as the stable financing method that can promote financial stability, growth, financial inclusion and generating long term employment. It precludes the unethical and unfair trade practices such as, riba, gharar, maisir, and excessive speculation etc. (Hassan and Soumar 2015). Islamic banking and finance has an important role in the development agenda of the MENA region due to its relevance in the overall development of the region as well as development of the individual countries in the region (Naceur \& Ghazouani, 2007). Though the current growth and potential development of Islamic banks is very promising among GCC nations but when observe other countries in the MENA region, the situation is not symmetric, as Islamic banking is relatively new with most of the banks are less than 40 years old and competing with each other. The recent technological advancements such as growth of Fintech and changes in customers' demand increase the complexity of the situation (Yu \& Hassan, 2008). Looking at the economic challenges such as financial inclusion, inequality of income and employment generation (Chowdhury \& Shumon, 2020) faced by the MENA countries, the role of Islamic finance becomes of utmost important as it is more suited to solve the issues of income inequality, financial inclusion and employment generation (Kim et al., 2018). A potential growth of Islamic finance is difficult to achieve in this region partly due to spread of banking assets across many institutions in the region. If Islamic finance want to grow and provide the alternative banking they need to be more customer centric which means they need to provide and customize its financial services according to the needs and demands of the customers in the specific countries and region (Boukhatem \& Ben Moussa, 2018).

Standard and Poor's (S\&P) report in June 2020 indicates that the pandemic offers a growth opportunity for the Islamic finance, which is more cohesive, transformative and consistent. Though Islamic finance industry grew at an overwhelming $11.4 \%$ in 2019 but the growth is expected to be in single digit during 2020-21 (S\&P, 2020). With appropriate coordination between different Islamic finance stakeholder and use of financial technology, Islamic 
Hassan, Rabbani, \& Abdullah | Socioeconomic Impact of COVID-19 in MENA region and the Role of Islamic Finance

finance has the potential to emerge as a new avenue for the investors as well as to serve as a sustainable finance model to various stakeholders (Sun et al., 2020).

\subsubsection{Solution to the health and economic crises and the role of Islamic finance}

The outbreak of COVID-19 pandemic, mainly a health emergency has disrupted all walk of social, political and economic life of the societies at all levels, especially the poor, daily wage laborers, marginal and vulnerable section of the society including small and micro enterprises (Mohammad et al., 2020). The economic damages caused by the pandemic is massive and it will take years to heal and recover (Sharif et al., 2020). Islam is the complete way of life and it has solution to the every challenges posed by the society, if the principles of Qur'an and Sunnah applied in the right spirit and direction ("Islamic Finance: Principles and Practice," 2010). Dealing issues like the current pandemic in Islamic finance must be addressed holistically including Islamic social finance (ISF), Islamic commercial finance (ICF) and policies of the government with respect to micro and macro policies. The pandemic has adversely affected the Islamic commercial finance and in this case the governments and Islamic social finance has to play the leading role in recovery during and post COVID. Historically, Islam has proved that the Islamic social finance is the way to go during the pandemic like these.

\subsubsection{Lesson from Crisis Management Policies of Umar bin Khattab}

Umar Bin Khattab (R.A.), second and longest serving caliphate among the Rashidun Caliphate in Islamic history faced a similar pandemic named as Amwas including severe drought and famine. It was so severe that people had nothing to eat, the livestock were dying, and wild animals came to the town and it was a huge panic among the people. People from the far flung areas travelled to the Madina Munawwara to seek help and advice from the caliphate Umar Bin Khattab (R.A.). Umar Bin Khattab (R.A.) is historically regarded and respected as one of the most dynamic and dedicated ruler who is also famous for serving rather than getting served (Patmawati, 2016). The caliphate took several policies which can be named as the tools of Islamic social finance to deal with the problem of the crises. The policies adopted by the caliphate Umar Bin Khattab (R.A.) included;

1. The Zakat collection on Livestock was abandoned and delayed due to the fact that several livestock died and also farmers could use these livestock for food purposes.

2. The reserve fund from Bait-UI-Maal was used to help the poor and affected people for food and medical purposes. 
Hassan, Rabbani, \& Abdullah | Socioeconomic Impact of COVID-19 in MENA region and the Role of Islamic Finance

3. The rich and people from the Madinah and nearby area was encouraged to donate heavily and help the affected people.

4. People were encouraged to slaughter their camels for food as they do not eat camel meat and even during emergency period.

5. The punishment for stealing the food was relaxed as people were finding hard to feed their families.

The basic spirit of Islam and its ethical principles of love for humanity, compassion, togetherness and global brotherhood remains same in every situation (Iqbal \& Lewis, 2009). Islamic finance has changed as it has adopted to the needs and requirements of the modern competitive world without compromising the basic ethos and principles of sharia. In the following section, we talk about the role and tools of Islamic social finance that can be utilized to fight the economic consequences caused by the pandemic.

\subsubsection{Islamic finance tools during and post COVID-19}

COVID-19 has caused a great damage to the real economy and it is the principal reason for the slowdown in the core Islamic finance markets and rising unemployment. The predominant migrant population in MENA region as well as comprehensive and timely stimulus package announced by the respective governments will absorb some of the shocks in the short run (Rabbani et al., 2021). However, in the long run, loss to several stakeholders is expected. Islamic Finance and its instruments can help the economy, banks, corporate and financial institutions to sustain and pass this difficult time. Some of the social instruments as described by (Hassan et al. 2020) that could be used during and as a post COVID measure are explained as follows:

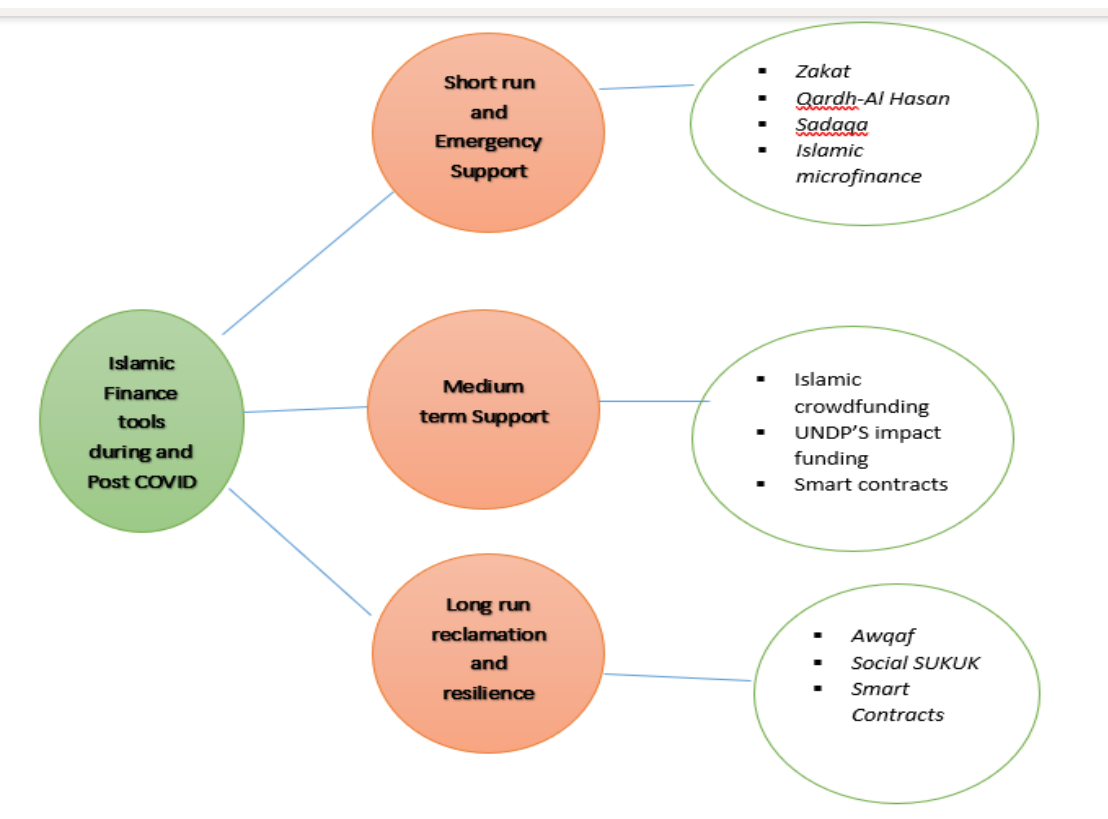

Figure 4. Islamic finance tools during and post COVID Source: adopted from Hassan et. Al, 2020 
Hassan, Rabbani, \& Abdullah | Socioeconomic Impact of COVID-19 in MENA region and the Role of Islamic Finance

Figure 4 shows that Islamic finance has a wide range of tools that can help and serve the society in times of crisis. Furthermore, if these Islamic tools is combined with the innovative technologies like Fintech it can be very useful to help the COVID affected and vulnerable parties of the society (M.R. Rabbani et al., 2021), (Rabbani, 2020). Financial technology (Fintech) is the use of innovative technology in delivering the financial services to the users (Atif et al., 2021), (Khan and Rabbani, 2020a; Khan 2020b). Islamic finance can play a vital role in the strategy of responses to COVID-19 as its tools can well suited to each stage of the pandemic (Rabbani et al, 2020).

Short run and Emergency Support: Islamic finance can cater to the needs of the poor and needy on immediate basis. In other words, the main objective of these tools is to help the poor and needy in times of need and crisis. Some of these short run emergency support services provided by the Islamic finance include.

Zakat: It is the compulsory charity from the eligible Muslims for the poor and needy every year. Muslims are required to contribute $2.5 \%$ of their wealth for the poor and needy every year. Zakat can be an important Islamic finance tool to provide immediate and urgent financial support. Often Zakat payers donate its Zakat money on cash basis and make it really a great financial tool to help the COVID affected people.

Islamic microfinance: Prior literature document that Islamic microfinance promotes entrepreneurship, boosts employment, reduces poverty and helps poor and vulnerable sections of the society (Alkhan \& Hassan, 2020). In times of COVID-19, Islamic microfinance can be used help the poor and vulnerable. As the basic feature of Islamic microfinance is to provide financial assistance to those who do not have access to the formal and traditional banking system. The poor and needy people are the most adversely affected parties in the society by the COVID and Islamic microfinance can be a lease of life for them.

Qardh-Al-Hasan: It is the interest free loan provided by the one party to another party based on benevolence. The principal is paid by the borrower to lender on due date without adding any markup. It is one of the most potential Islamic finance tools to help the COVID-19 affected individuals and SMEs if combined with the Fintech (Mohammad et al., 2020).

Sadaqa: It is the voluntary donation by Muslims for the poor and needy and the amount of Sadaqa is purely at the will of the 'donor'. Holy Prophet Muhammad described Sadaqa and Du'a as the two-miracle arrow in Islam's squiver. It can potentially be used to help the Muslims affected by the COVID19 by direct cash transfer or by transferring other non-cash benefits. 
Hassan, Rabbani, \& Abdullah | Socioeconomic Impact of COVID-19 in MENA region and the Role of Islamic Finance

Medium term Support: The biggest challenge which will arise after diminish of the pandemic is the need of financing source for equipment, machines, and tools. Islamic banks can play an important role in financing of these facilities to the COVID-19 affected people and institutions and support their recovery in the medium term. The most important and notable Islamic financing tool could be the sharia compliant crowdfunding for raising capital. Sharia compliant crowdfunding platforms are the innovative and disruptive financial innovation for raising money from the market without intermediaries like banks and other financial instructions. The other tools can be sharia compliant smart contracts based on Mudaraba, Murabaha and Musharaka. Smart contracts are the financial innovation using Blockchain technology which automatically executes the terms of the contract upon the due date. Islamic banks could take this as an opportunity and align their financing activities with the UN-SDG's (United Nations Sustainable Development Goals). In 2018, AlBaraka banking group launched a 600 Million US\$ initiative in collaboration with UNDP for the regions like MENA, Asia and Europe (UNDP, 2020). The pandemic shed light on the importance and the need for similar initiatives to provide more relief to the poor and vulnerable sections of the society affected by the pandemic (Khan \& Rabbani, 2021).

Long run reclamation and resilience: Islamic financial instruments like social Sukuk, Awqaf and smart contracts can be the potential warrior in fight against the economic consequences of the COVID-19. The social Sukuk can be aligned with the UN-SDGs to help poor and vulnerable governments mainly in African part of the MENA region. Waqf is the endowment made by the Muslims for the social, religious and benevolent reason. In case of Waqf, financial and nonfinancial assets are donated for the social cause on permanent basis (Sun et al., 2020).

COVID-19 has provided an opportunity for stakeholders to tackle the devastation created by the pandemic and invest in sustainable development. Islamic financial is the most suited and resilient financial system in crises as it has appropriate financing tools available at each stage of the crisis (Kim et al., 2018). With innovative technologies like Fintech this battle must be fought and won by the Islamic financial institutions (Rabbani et al., 2020). 
Hassan, Rabbani, \& Abdullah | Socioeconomic Impact of COVID-19 in MENA region and the Role of Islamic Finance

\section{Conclusion and Recommendation}

\subsection{Conclusion}

COVID-19 has inflicted havoc in the almost everyone's lives across the globe, and MENA region is not an exception. It has created damage to the individuals and organization in the region that will require substantial time and resources to recover the economy. This paper analyzes the socio-economic impact of COVID-19 on MENA region and role of Islamic finance. The pandemic has started as a health crisis but then became an economic recession due to low demand caused by social distancing, shut down policies, and fear. This low demand in turn had affected the supply side which resulted in the closures of some companies, laid of employees and low revenues.

We conclude that though the number of direct cases remain higher in the GCC part of the region but it is the African continent of the region which is more susceptible and vulnerable due to the economic damage caused by the pandemic. Despite the high number of cases and death rates in GCC countries, they are expected to have a $\mathrm{V}$-shaped recovery due to their strong financial and policy reforms. Whereas, other countries in the Arab region like Yemen Syria are already war ridden; and high volume of national debt will find it difficult to recover and find stability post COVID-19. It is the African side of the region which needs to rethink its exposure to the global economy and spillover repercussions for African countries in the MENA region. Several questions arise at this stage such as whether the negative impact of globalization is more than the positives? With a little or no support from the stronger and more powerful economies in the region, will they reduce their dependencies on them? Will the countries like Bahrain and Kuwait reduce their dependency on oil revenue due to the consistent and sharp fall in the oil prices due to pandemic? Future studies may try to find answers for these questions as well it might be interesting for further studies to examine the direct financial impact of COVID 19 on MENA region.

This paper also analyzes the role of Islamic finance during and post COVID-19 period in MENA region. The findings indicate that Islamic finance and banking, which has proven its importance during and post financial crisis of 2008, is expected to play the same role in recovery from the economic shock created by the pandemic. The growing adoption of financial technology (Fintech) by the Islamic financial institutions will boost the prospects of IFIs in quick and speedy recovery from the shock. Bahrain is the country with largest strength of Islamic financial institutions in the region, on the other hand Kuwait and Saudi Arabia are having the largest asset per bank followed by the UAE and Qatar. To conclude, Islamic finance and banking is expected to be more 
Hassan, Rabbani, \& Abdullah | Socioeconomic Impact of COVID-19 in MENA region and the Role of Islamic Finance

resilient in crisis as shown during the financial crisis mainly due to the fact that its financing is based on the real economy and it avoids the interest based transactions and investment in toxic assets like financial derivatives.

\subsection{Recommendations}

Based on the findings of the study, the following recommendations are suggested. A more integrated effort between the different department of the governments, private organizations and civil societies are needed to tackle the economic mayhem created by the pandemic. It is suggested that Islamic finance institutions are to be given more role in fighting the economic adversities of the pandemic. Islamic finance has certain social financing tools like Zakat, Qardh-Al-Hasan, Social SUKUK etc. which are tailor made for the situation like COVID-19 (Ali et al. 2020; Rabbani et al. 2020). COVID-19 pandemic has given acceptance and popularity to the technology based financial services and Islamic finance in combination with the Islamic Financial technology (Fintech) has the capacity to emerge as the winner and challenge the conventional financial system. It is further recommended that governments across the MENA region must show more trust towards the Islamic financial system and stimulus packages announced during and after pandemic must go through the Islamic financial system. 
Hassan, Rabbani, \& Abdullah | Socioeconomic Impact of COVID-19 in MENA region and the Role of Islamic Finance

\section{References}

Achou, B., Boisclair, D., D’Astous, P., Fonseca, R., Glenzer, F., \& Michaud, P.-C. (2020). Early Impact of the COVID-19 pandemic on household finances in Quebec. Canadian Public Policy, 46(3), S217-S235. https://doi.org/10.3138/CPP.2020-087

Ali, M. M., Bashar, A., Rabbani, M. R., \& Abdullah, Y. (2020). Transforming Business Decision Making with Internet of Things ( IoT ) and Machine Learning ( ML ). 2020 International Conference on Decision Aid Sciences and Application (DASA), Sakheer, Bahrain, 2020, Pp. 674-679, Doi: 10.1109/DASA51403.2020.9317174.

Alkhamis, A., Hassan, A., \& Cosgrove, P. (2014). Financing healthcare in Gulf Cooperation Council countries: A focus on Saudi Arabia. International Journal of Health Planning and Management. https://doi.org/10.1002/hpm.2213

Alkhan, A. M., \& Hassan, M. K. (2020). Does Islamic microfinance serve maqāsid al-shari'a? Borsa Istanbul Review. https://doi.org/10.1016/j.bir.2020.07.002

Atif, M., Hassan, M. K., Rabbani, M. R., \& Khan, S. (2021). 6 Islamic FinTech. In COVID-19 and Islamic Social Finance, 91.

Aydın, L., \& Ari, I. (2020). The impact of Covid-19 on Turkey's non-recoverable economic sectors compensating with falling crude oil prices: A computable general equilibrium analysis. Energy Exploration and Exploitation, 38(5), 1810-1830. https://doi.org/10.1177/0144598720934007

Boukhatem, J., \& Ben Moussa, F. (2018). The effect of Islamic banks on GDP growth: Some evidence from selected MENA countries. Borsa Istanbul Review. https://doi.org/10.1016/j.bir.2017.11.004

Catherine, S., Miller, M., \& Sarin, N. (2020). Relaxing household liquidity constraints through social security. Journal of Public Economics, 189. https://doi.org/10.1016/j.jpubeco.2020.104243

Chowdhury, P., \& Shumon, R. (2020). Minimizing the gap between expectation and ability: Strategies for smes to implement social sustainability practices. Sustainability (Switzerland), 12(16). https://doi.org/10.3390/SU12166408

Czeczeli, V., Kolozsi, P. P., Kutasi, G., \& Marton, Á. (2020). Economic exposure and crisis resilience in exogenous shock: The short-term economic impact of the covid-19 pandemic in the EU. Public Finance Quarterly, 65(3), 321-347. https://doi.org/10.35551/PFQ_2020_3_1

Damak, M., Roy, D., \& Mensah, S. (2020). Islamic Finance 2020-2021: COVID19 Offers An Opportunity For Transformative Developments. S\&P Global. 
DinarStandard. (2019). State of the Global Islamic Economy Report 2019/20. In Dubai International Financial Centre.

DinarStandard. (2020). State of the Global Islamic Economy Report 2020/21. In Dubai International Financial Centre. https://haladinar.io/hdn/doc/report2018.pdf

Dureab, F., Al-Awlaqi, S., \& Jahn, A. (2020). COVID-19 in Yemen: preparedness measures in a fragile state. In The Lancet Public Health. https://doi.org/10.1016/S2468-2667(20)30101-8

Duszak, R., Maze, J., Sessa, C., Fleishon, H. B., Golding, L. P., Nicola, G. N., \& Hughes, D. R. (2020). Characteristics of COVID-19 Community Practice Declines in Noninvasive Diagnostic Imaging Professional Work. Journal of the American College of Radiology, 17(11), 1453-1459. https://doi.org/10.1016/j.jacr.2020.06.031

Ehrlich, J. A., Ghimire, S., Khraiche, M., \& Raza, M. F. (2020). COVID-19 countermeasures, sporting events, and the financial impacts to the North American leagues. Managerial Finance. https://doi.org/10.1108/MF-05-2020-0275

Eichenauer, V., \& Sturm, J.-E. (2020). The economic policy measures of Switzerland at the beginning of the COVID-19 pandemic . Perspektiven Der Wirtschaftspolitik, 21(3), 290-300. https://doi.org/10.1515/pwp2020-0027

Erceg, N., Ružojčić, M., \& Galić, Z. (2020). Misbehaving in the Corona crisis: The role of anxiety and unfounded beliefs. Current Psychology. https://doi.org/10.1007/s12144-020-01040-4

GCC-STAT. (2020). final report covid19.pdf.

Ghani, F. (2020). Covid-19 outbreak - immediate and long-term impacts on the dental profession. Pakistan Journal of Medical Sciences, 36(COVID19-S4), S126-S129. https://doi.org/10.12669/pjms.36.COVID19-S4.2698

Hassan, M. K., Rabbani, M. R., \& Ali, M. A. (2020). Challenges for the Islamic Finance and banking in post COVID era and the role of Fintech. Journal of Economic Cooperation and Development, 43(3).

Hassan, M.K., \& Rabbani, M. R. (2021). Islamic Fintech, Blockchain \& Crowdfunding: current landscape \& path forward.

Hassan, M.K., Rabbani, M. R., Atif, M., \& Ali, A. M. (2021). Sharia governance of Islamic financial institutions and the role of AAOIFI: A systematic literature review and future research agenda. Journal of Islamic Accounting and Business Research, In press.

Hassan, M.K., Rabbani, M. R., Khan, S., \& Ali, M. A. M. (2021). An Islamic Finance Perspective of Crowdfunding and Peer to Peer Lending. 
Hassan, Rabbani, \& Abdullah | Socioeconomic Impact of COVID-19 in MENA region and the Role of Islamic Finance

Hassan, M Kabir, \& Soumar\&\#xe9;, I. (2015). Guarantees and Profit-Sharing Contracts in Project Financing. Journal of Business Ethics.

Hepburn, C., O'Callaghan, B., Stern, N., Stiglitz, J., \& Zenghelis, D. (2020). Will COVID-19 fiscal recovery packages accelerate or retard progress on climate change? Oxford Review of Economic Policy, 36, S359-S381. https://doi.org/10.1093/oxrep/graa015

IMF. (2020). Policy Responses to COVID19. In Imf.

Iqbal, Z., \& Lewis, M. K. (2009). An islamic perspective on governance. In An Islamic Perspective on Governance. Edward Elgar Publishing Ltd. https://doi.org/10.4337/9781848449220

Islamic Development Bank Group. (2020). the Covid-19 Crisis and Islamic Finance (Issue September). https://irti.org/product/the-covid-19crisis-and-islamic-finance/

Islamic finance: principles and practice. (2010). Choice Reviews Online. https://doi.org/10.5860/choice.48-2205

Khan, S., Hassan, M. K., \& Rabbani, M. R. (2021). An Artificial Intelligencebased Islamic FinTech model on Qardh-Al-Hasan for COVID 19 affected SMEs. In ISLAMIC PERSPECTIVE FOR SUSTAINABLE FINANCIAL SYSTEM (p. In press).

Khan, Shahnawaz;, \& Rabbani, M. R. (2021). Artificial Intelligence and NLP based Chatbot as Islamic Banking and Finance Expert. International Journal of Information Retrieval Research, In press.

Khan, Shahnawaz, \& Rabbani, M. R. (2020). Chatbot as Islamic Finance Expert (CalFE): When finance meets Artificial Intelligence. 2020 International Conference on Computational Linguistics and Natural Language Processing (CLNLP 2020), Seoul, South Korea.

Khan, Shahnawaz, \& Rabbani, M. R. (2021). In Depth Analysis of Blockchain, Cryptocurrency and Sharia Compliance. International Journal of Business Innovation and Research, In press, In press. https://doi.org/10.1504/ijbir.2020.10033066

Kim, D. W., Yu, J. S., \& Hassan, M. K. (2018). Financial inclusion and economic growth in OIC countries. Research in International Business and Finance. https://doi.org/10.1016/j.ribaf.2017.07.178

Li, T., Chung, H. K., Pireku, P. K., Beitzel, B. F., Sanborn, M. A., Tang, C. Y., Hammer, R., Ritter, D., Wan, X., Berry, I. M., \& Hang, J. (2020). Rapid High Throughput Whole Genome Sequencing of SARS-CoV-2 by using One-step RT-PCR Amplification with Integrated Microfluidic System and Next-Gen Sequencing. BioRxiv.

McKibben, W., \& Fernando, R. (2020). Centre for Applied Macroeconomic Analysis The Global Macroeconomic Impacts of COVID-19: Seven Scenarios. Centre for Applied Macroeconomic Analysis. 
Hassan, Rabbani, \& Abdullah | Socioeconomic Impact of COVID-19 in MENA region and the Role of Islamic Finance

Mohammad, Khan, S., Mustafa, \& Yannis. (2020). An Artificial Intelligence and NLP based Islamic FinTech Model Combining Zakat and Qardh-AlHasan for Countering the Adverse Impact of COVID 19 on SMEs and Individuals. International Journal of Economics and Business Administration. https://doi.org/10.35808/ijeba/466

Naceur, S. Ben, \& Ghazouani, S. (2007). Stock markets, banks, and economic growth: Empirical evidence from the MENA region. Research in International Business and Finance. https://doi.org/10.1016/j.ribaf.2006.05.002

Nicola, M, Alsafi, Z., Sohrabi, C., Kerwan, A., Al-Jabir, A., Iosifidis, C., Agha, M., \& Agha, R. (2020). The socio-economic implications of the coronavirus pandemic (COVID-19): A review. International Journal of Surgery, 78, 185-193. https://doi.org/10.1016/j.ijsu.2020.04.018

Nicola, Maria, Alsafi, Z., Sohrabi, C., Kerwan, A., Al-Jabir, A., Iosifidis, C., Agha, M., \& Agha, R. (2020). The socio-economic implications of the coronavirus pandemic (COVID-19): A review. In International Journal of Surgery. https://doi.org/10.1016/j.ijsu.2020.04.018

Ozili, P. (2020a). COVID-19 in Africa: socio-economic impact, policy response and opportunities. International Journal of Sociology and Social Policy. https://doi.org/10.1108/IJSSP-05-2020-0171

Ozili, P. (2020b). COVID-19 in Africa: socio-economic impact, policy response and opportunities. International Journal of Sociology and Social Policy, 99617. https://doi.org/10.1108/IJSSP-05-2020-0171

Ozili, P. K., \& Arun, T. (2020). Spillover of COVID-19: Impact on the Global Economy. SSRN Electronic Journal. https://doi.org/10.2139/ssrn.3562570

Patmawati, P. (2016). DAKWAH PADA MASA UMAR BIN KHATTAB. Al-Hikmah. https://doi.org/10.24260/al-hikmah.v10i1.544

Rabbani, M. R., Khan, S., Hassan, M. K., \& Ali, M. (2021). 7 Artificial intelligence and Natural language processing (NLP) based FinTech model of Zakat for poverty alleviation and sustainable development for Muslims in India. In ICOVID-19 and Islamic Social Finance: 104.

Rabbani, M. R., Ali, M. A. M., Rahiman, H., Atif, M., Zulfikar, Z., \& Naseem, Y. (2021). The response of Islamic financial service to Covid-19 pandemic: The social open innovation of financial system. Journal of Open Innovation: Technology, Market, and Complexity.

Rabbani, M. R. (2020). The competitive structure and strategic positioning of commercial banks in Saudi Arabia. International Journal on Emerging Technologies, 11(3), 43-46.

Rabbani, Mustafa Raza, Abdullah, Y., Bashar, A., Khan, S., \& Ali, M. A. M. (2020). Embracing of Fintech in Islamic Finance in the post COVID era. 
Hassan, Rabbani, \& Abdullah | Socioeconomic Impact of COVID-19 in MENA region and the Role of Islamic Finance

$$
\begin{aligned}
& 2020 \text { International Conference on Decision Aid Sciences and } \\
& \text { Application (DASA), Sakheer, Bahrain, 2020, Doi: } \\
& \text { 10.1109/DASA51403.2020.9317196., 1230-1234. }
\end{aligned}
$$

Rabbani, M. R., Khan, S., \& Thalassinos, E. I. (2020). FinTech, blockchain and Islamic finance: An extensive literature review. International Journal of Economics and Business Administration, 8(2), 65-86. https://doi.org/10.35808/ijeba/444

Salisu, A. A., Ebuh, G. U., \& Usman, N. (2020). Revisiting oil-stock nexus during COVID-19 pandemic: Some preliminary results. International Review of Economics and Finance, 69, 280-294. https://doi.org/10.1016/j.iref.2020.06.023

Setiawan, R., Nashrullah, M. R., Mulyani, A., \& Mubarok, M. S. (2019). Architecture information system for zakat, infaq and sadaqah management institutions (A. A.G., N. A.B.D., W. I., D. A.A., \& A. C.U. (Eds.); Vol. 1402, Issue 2). Institute of Physics Publishing. https://doi.org/10.1088/1742-6596/1402/2/022082

Sharif, A., Aloui, C., \& Yarovaya, L. (2020). COVID-19 pandemic, oil prices, stock market, geopolitical risk and policy uncertainty nexus in the US economy: Fresh evidence from the wavelet-based approach. International Review of Financial Analysis. https://doi.org/10.1016/j.irfa.2020.101496

Singer, A. (2006). Soup and sadaqa: Charity in Islamic societies. Historical Research. https://doi.org/10.1111/j.1468-2281.2006.00363.x

Sun, H., Rabbani, M. R., Sial, M. S., Yu, S., Filipe, J. A., \& Cherian, J. (2020). Identifying Big Data's Opportunities, Challenges, and Implications in Finance. Mathematics, 8(10). https://doi.org/https://doi.org/10.3390/math8101738

Sun, Huidong;, Rabbani, M. R., Naveed, A., Sial, M. S., Guping, C., Zia-ud-din, M., \& Fu, Q. (2020). CSR, Co-Creation and Green Consumer Loyalty: Are Green Banking Initiatives Important? A Moderated Mediation Approach from an Emerging Economy. Sustainability (Switzerland), 12(24), 10688.

Syed, M. H., Khan, S., Rabbani, M. R., \& Thalassinos, Y. E. (2020). An artificial intelligence and NLP based Islamic FinTech model combining zakat and Qardh-Al-Hasan for countering the adverse impact of COVID 19 on SMEs and individuals. International Journal of Economics and Business Administration, 8(2), 351-364. https://doi.org/10.35808/IJEBA/466

The, F. O. R., \& Eastnorth, M. (2018). NEW (Issue October).

UNDP. (2020). 2020 Human Development Perspective Tackling Social Norms: A game changer for gender inequalities. United Nations Development Programme. 
Hassan, Rabbani, \& Abdullah | Socioeconomic Impact of COVID-19 in MENA region and the Role of Islamic Finance

Wodak, R., \& Meyer, M. (2011). Methods of Critical Discourse Analysis. In Methods of Critical Discourse Analysis. https://doi.org/10.4135/9780857028020

Wójcik, D. (2020). Financial geography II: The impacts of FinTech - Financial sector and centres, regulation and stability, inclusion and governance. Progress in Human Geography. https://doi.org/10.1177/0309132520959825

World Bank. (2020). Food Security and Covid-19. Understanding Poverty.

Yu, J. S., \& Hassan, M. K. (2008). Global and regional integration of the Middle East and North African (MENA) stock markets. Quarterly Review of Economics and Finance. https://doi.org/10.1016/j.qref.2006.06.003 
Hassan, Rabbani, \& Abdullah | Socioeconomic Impact of COVID-19 in MENA region and the Role of Islamic Finance

This page is intentionally left blank. 